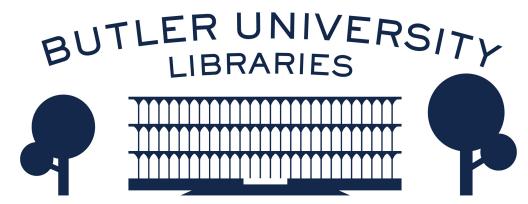

Journal of Hindu-Christian Studies

Volume 31 Celebrating Rāmānuja at 1000: The

Heritage and Promise of the Study of Rāmānuja

in a Christian-Hindu Comparative Theology

Article 37

2018

\title{
Book Review: Ethnic Church Meets Megachurch: Indian American Christianity in Motion
}

Amanda Lucia

University of California-Riverside

Follow this and additional works at: https://digitalcommons.butler.edu/jhcs

\section{Recommended Citation}

Lucia, Amanda (2018) "Book Review: Ethnic Church Meets Megachurch: Indian American Christianity in Motion," Journal of Hindu-Christian Studies: Vol. 31, Article 37.

Available at: https://doi.org/10.7825/2164-6279.1717

The Journal of Hindu-Christian Studies is a publication of the Society for Hindu-Christian Studies. The digital version is made available by Digital Commons @ Butler University. For questions about the Journal or the Society, please contact cbauman@butler.edu. For more information about Digital Commons @ Butler University, please contact digitalscholarship@butler.edu. 
inconclusive. Perhaps this community is too idiosyncratic, the tradition too tied to structures and intransigent theologies born of different soil. We should note in closing that the challenges to Catholic ecclesiology are problems for the Indian Catholic Church, not necessarily for the Khrist Bhaktas. As is their wont, they continue to worship Yesu, Mata Mariayam and other saints as they are able, with all the Hindu/Christian/human tools at their disposal. They do so on terms often mediated by the Catholic Church in a charismatic, top-down, semi-acculturated register, but there is certainly no guarantee that this shall continue indefinitely.

Kerry P. C. San Chirico

Villanova University

\section{Ethnic Church Meets Megachurch: Indian American Christianity in Motion. By Prema A. Kurien. New York: New York University Press, 2017, xiv +279 pages.}

PREMA Kurien's Ethnic Church Meets Megachurch supplies the field with an important sociological account of the transnational religious and ethnic contestations within the Mar Thoma church, a Syrian Christian church based in Kerala. Her extensive ethnographic research, dating back to 1999 , is a refreshingly data-rich study that is longitudinally oriented in its inclusion of the extensive history of the Mar Thoma church since its inception in the early decades of the Christian era. It is also a geographically cross-sectional study in its attention to the transnational intersections between the Mar Thoma church in India and in the United States. Kurien's data reveals that research on religion and ethnicity in the United States must account for generational differences and specific nuances of a particular ethnic denomination's negotiations in multicultural America.

Most provocatively, Kurien's research demonstrates that second-generation Indian American Christians of the Mar Thoma church are decoupling ethnicity from religion by choosing to worship in multiracial, nondenominational evangelical Christian congregations. She reveals how they are adopting American evangelical ideals of "antitradition, antiliturgical, and individual worship orientation" (110) and centralizing the experience of personal salvation and the importance of proselytization. At times, one can almost hear Kurien mourning for the loss of a tradition-centric, liturgically heavy, Malayalam-based locus of support and community for immigrant Malayalee Christians (only 20-30 percent of the second and third generation attend the Mar Thoma church on a regular basis) (114). This is compounded by her legitimate fear that the second-generation millennials who are turning away from their parents' ethnic churches may lose the support system of the ethnic church that their parents built and become lost in "anonymous and impersonal gatherings" (243). However, this hint of lament is heavily veiled by Kurien's datadriven sociological account, which allows such generational fissures to exist in unresolved tension in their own voices derived from her extensive interviews and results in a substantive and enduring scholarly contribution.

Kurien's findings are quite anomalous in the field of ethnicity and religion in the United 
States; therefore, they warrant particular scholarly attention. The centrality of the ethnic church is one of the basic points of consensus among scholars in the fields of Asian-American and Asian religions in the United States. A myriad of studies of religion and ethnicity in the United States have demonstrated how minority groups in the United States build communal strength through religious institutions and how churches, temples, and mosques provide additional resources to minority communities above and beyond their religious function. Religious institutions become de facto safe havens, schools, cultural centers, language learning institutions, restaurants, public relations interlocutors, immigration liaisons, and activists for political and social causes. This is particularly true for non-dominant religions in the United States (Hinduism, Buddhism, Jainism, Sikhism, Islam), but scholars of East Asian American Christians also agree that ethnicity and religion are intertwined and mutually reinforcing in Asian American Christianity (128). Because of their racialization outside of ethnic churches, East Asian American Christians return to the safehaven of the ethnic church after "feeling marginalized" in large multi-ethnic evangelical churches. In contrast, the secondgeneration Mar Thomites that Kurien interviewed preferred multi-ethnic evangelical churches and downplayed incidents of racism as isolated encounters. Instead, they emphasized the importance of "culture-free" Christianity (128). Kurien suggests that their assimilation into dominant strains of American evangelical Christianity may be because Indian Americans have smaller and more diverse social networks than East Asian Americans, which may make them more comfortable in white or multiracial religious communities (141). Once established in emotive and entertainment-oriented evangelical services, these second-generation millennials begin to find fault with the formal, Malayalee liturgy, the first-generation leadership, and the exclusive Indianness of the Mar Thoma church (209).

Kurien divides her book into six chapters. The first chapter is a lengthy account of the pre-colonial and colonial Mar Thoma church in India. The second outlines the church's role for first-generation immigrants in the United States, while the third chapter reveals the second-generation's decoupling of religion and ethnicity in the United States and its critiques of the Mar Thoma church. The fourth chapter includes an intersectional analysis of the impacts of race, class, and gender on Mar Thomite values in the United States. The fifth chapter returns to the generational divisions highlighted in chapter three by focusing on generationally distinct ideals of social engagement and religion. Chapter six guides readers back to India to witness the changes that international migration has had on the Mar Thoma church in India.

The trajectory of these chapters carries readers from early Syrian Christianity and colonial encounters in India to Mar Thomites' negotiations of religion and ethnicity in the United States, and then back to India with a focus on the impact of emigration on the Mar Thoma Denomination globally. Her chapters aim rectify what she views as "the biggest limitation of migration studies frameworks," which is that "they currently focus primarily on the one-directional influence of either the home or host country instead of examining the impact of both home and host societies on migrants, as well as the impact of migration on home and host societies" (245). She continues, "similarly, frameworks of religious change are currently focused on national processes" (245). While I agree with Kurien's attention to 
the global, dynamic, and multi-sited nature of transnational religion, these two sentences, both without citation as to the author's subjectival referent, are emblematic of the author's tendency to speak in general terms of theories or scholarship on transnational religion. This tendency weakens what is a very strong work, and leads educated readers to conjure exceptions, mentally accumulating a bibliography of scholars who address the multi-sited and global dynamics of transnational religion. Further, by detailing both the Indic and US contexts from precolonial to present, Kurien holds high expectations for one book. While she is largely successful, there were times when a more contextualized investigation into any one of these foci may have been useful, particularly the differences between various Asian ethnic congregations in the United States, since her data complicates a scholarly consensus in this field. She concludes, "it is important not to take the studies of East Asian American Christians as the last word on the interaction between race and religion [in the United States]" (242). Agreed, but how would the data look if we included research on Asian nonChristians or non-Asian ethnic minority Christians? Certainly, we cannot sound the death knell for ethnic congregations in the United States when for many ethnic and religious minorities they remain the primary sites for worship.

In short, Kurien's book is wonderful to think with and provides a provocative, evidence-driven account, which complicates existing conventions in scholarship. That is to say, it is solid, well-crafted, substantive scholarship, which will be useful and effective for scholarly and undergraduate audiences alike.

Amanda Lucia

University of California-Riverside

\section{The Past, Present, and Future of Theologies of Interreligious Dialogue. Edited by Terrence Merrigan \& John Friday. Oxford: Oxford University Press, 2017, xi +259 pages.}

THEOLOGICAL discourses on interreligious dialogue within the Roman Catholic Church flourished especially after Vatican II (1962-65). In this volume, Terrance Merrigan and John Friday compile some of these theologies and theologians into a conversation. Written primarily for those committed to critical reflection on interreligious dialogue and its study and practice, these essays discuss the historical antecedents, current trends, and future possibilities for the field. This volume is a sure sign of the maturity of interreligious dialogue as a field of study and a welcome addition to the continuing conversations.
The volume is divided into three sections to focus on the past, present, and future of the theologies of interreligious dialogue. Part I, comprising the first five chapters, interprets various canonical documents that influenced the basic attitudes of the Roman Catholic Church towards other faith traditions and thus contributed to interreligious dialogue. The writers focus on doctrinal nuances in the church documents related to dialogue and summarize select theologians who contributed to the field of interreligious dialogue. This part is a helpful and engaging introduction to the history of interreligious dialogue in the Catholic Church. 